\title{
Herpes Zoster in Patients with Polymyositis and Dermatomyositis
}

\author{
Shohei NAGAOKA, Kenji TANI, Yoshiaki ISHIGATSUBO, Jun CHIBA \\ Kiyoshi KATO, Keiichiro MATSUNAGA, Masahiro NARITA, \\ Toshihisa IGARASHI and Takao OKUBO
}

The First Department of Internal Medicine, Yokohama City University, School of Medicine

Key words: Herpes zoster, Dermatomyositis, Polymyositis

\begin{abstract}
Twenty-two patients with polymyositis and dermatomyositis (PM-DM) were retrospectively studied with regard to development of herpes zoster.

Herpes zoster occurred with high frequency in patients with PM-DM. The clinical courses of zoster infections were uneventful; no severe complications nor deaths occurred, and only one patient had postherapeutic neuralgia. No specific therapy for this infection was necessary. Zoster tended to occur in the inactive stage of PM-DM. PM-DM patients with herpes zoster had a significantly higher incidence of antinuclear antibody. There seemed to be no relationship between steroid therapy and herpes zoster infection.
\end{abstract}

\section{Introduction}

PM-DM are diffuse inflammatory diseases of the striated muscle wich may lead to muscle atrophy and proximal muscle weakness involving the limb, pharynx, face and neck. The etiology of PM-DM is an autoimmune disease mediated lymphocytes ${ }^{1)}$ and that some patiets have humoral immuodeficiency ${ }^{2}$. Such patients have a susceptibility to infections, and corticosteroid therapy may lead to further reduction in host defence to infection ${ }^{3)}$.

Herpes zoster, an inflammatory human disease by the varicella-zoster virus, is characterized by papulovesicular along several dermatomes. The varicella-zoster virus may produce varicella as a primary infection and herpes zoster as a secondary infection. Zoster represents reactivation of latent varicellazoster virus that has remained dormant in the dorsal root ganglia, the activation being caused by aging, radiation, immunosuppressive agents and so $\mathrm{on}^{4}$ ). In addition, this infection appears to be more frequent in certain immunocompromised patients ${ }^{5}$.

In the present study, the clinical characteristics of herpes zoster infections in patients with PM-DM are retrospectively analyzed. In addition, we examined possible predisposing factors of zoster infections in these patients.

\section{Materials and Method}

\section{Subjects}

The clinical records of all patients with a diagnosis of polymyositis or dermatomyositis from the First Department of Internal Medicine, Yokohama City University Hospital during the interval 1973 through 1983 were reviewed retrospectively and certain features were critically evaluated: Twenty-two patients

\footnotetext{
別刷請求先：(宁232）横浜市南区浦舟町 3-46 横浜市立大学医学部第 1 内科 
who had no family history of myopathy and who fulfilled the Bohan's criteria were selected ${ }^{6}$. Twenty cases of non Hodgkin's lymphoma and twenty-two cases of SLE in whom age of patients was matched to it of PM-DM patients, were studied as a disease control (Table 1). The American Rheumatism Association criteria were used for selecting patients with $\mathrm{SLE}^{7}$. All patiens with these diagnosis were seen by authors.

The diagnosis of herpes zoster was accepted if varicella-zoster virus was isolated from skin lesions. In those ptients with absence of viral cultures, seologic tests, i.e. herpes zoster titer in the serum increasing more than 4 times, were done on these patients to support the conclusion of the diagnosis.

Laboratory tests Antinuclear antibody was measured using an indirect immunofluorescent technique ${ }^{8 /}$ and rat liver as substrate. A reaction was considered positive at a titre of 1:20 or greater.

Anti-DNA antibodies were measured using a DNA binding technique ${ }^{9}$.

Herpes zoster titer in the serum was measured using the method described elsewhere ${ }^{10)}$.

Statistical analysis Correlation between herpes zoster and other features in patients with PM-DM studied retrospectively were evaluated using $t$ test.

\section{Results}

\section{Incidence of Herpes Zoster in Patients with Polymyositis and Dermatomyositis}

Five of the 22 patients with PM-DM (22.7\%) had a history of herpes zoster infection during 180.4 observation years. On the other hand, $40.9 \%$ of the patients with SLE during 171.6 observation years, $10.0 \%$ of those with non Hodgkin's lymphoma developed zoster during observation 56 years (Table 1).

The duration of PM-DM in these patients prior to the time of development of herpes zoster varied from eleven to 93 months. All cases tended to have an inactive stage of PM-DM when they had an attack of herpes zoster: 4 patients were an inactive stage of PM-DM at the time of herpes zoster infection and only

Table 1 Incidence of Herpes Zoster in Patients with PM-DM

\begin{tabular}{|c|c|c|c|c|}
\hline & $\begin{array}{c}\text { Age } \\
\text { (mean age) }\end{array}$ & No. of Patients & $\begin{array}{c}\text { No. of Patients } \\
\text { with Herpes Zoster } \\
(\%)\end{array}$ & $\begin{array}{l}\text { Observation period } \\
\text { (years) }\end{array}$ \\
\hline $\mathrm{PM}$ and $\mathrm{DM}^{*}$ & $\begin{array}{c}20-48 \\
(36.2 \pm 6.1)\end{array}$ & 22 & $5(22.7)$ & 180.4 \\
\hline SLE & $\begin{array}{c}20-48 \\
(32.6 \pm 5.8)\end{array}$ & 22 & $9(40.9)$ & 171.6 \\
\hline Non Hodgkin's lymphoma & $\begin{array}{c}22-49 \\
(30 \pm 4.9)\end{array}$ & 20 & $2(10.0)$ & 52.0 \\
\hline
\end{tabular}

*The two patients of PM overlapped with classical RA or SLE.

Table 2 Clinical Manifestations of Herpers Zoster in 5 Patients with PM-DM

\begin{tabular}{ll}
\hline Zoster distributions & \\
$\quad$ Thoarcic area & 3 patients \\
Lumbosacral area & 2 patients \\
Durations of herpers zoster & $10-30$ days \\
Multiple episodes & 0 patients \\
Dissminated zoster & 0 patients \\
Post herpetic neuralgia & 1 patients \\
Interval to the development of herpes zoster from the onset of & $11-93$ months \\
PM-DM & (average 38.6 months) \\
Activity of myositis & 4 patients \\
$\quad$ Inactive & 1 patient \\
$\quad$ Slight increase of serum muscular enzyme & \\
\hline
\end{tabular}


one had a slight elevation of serum aldolase without clinical muscle manifestations when zoster developed.

Clinical Manifestations of Herpes Zoster in Five Patients with PM-DM (Table 2)

The dermatomal distributions of herpes zoster were thoracic (3 cases) and lumbosacral area (2 cases). The duration from onset to disappearing of all symptoms of herpes zoster ranged from 10 to 30 days with an average duration of 17.6 days. No patients had multiple episodes. In clinical courses of herpes zoster, there were no severe complications such as disseminated zoster and death. Only one of the five patients had persistent neuralgia of the left Th-10 area at the age 69. Interval to the attack of herpes zoster from the onset to PM-DM ranged from 1 to 93 months with an average duration of 38.6 months. Activity changes of myositis by herpes zoster infection were as follows: four patients were inactive and one patient had a slight increase of serum muscular enzyme.

These patients did not receive specific therapy for herpes zoster.

Relationship between Herpes Zoster Infection and Clinical and Laboratory Manifestations of PM-DM (Table 3)

The five patients with herpes zoster infection were compared with the seventeen patients without zoster infection, with regard to difference in sex, age at onset of PM-DM, and frequencies of manifestations of PM-DM (both clinical and laboratory).

The sex distribution and mean age at onset of PM-DM were not significantly different between the two groups.

As noted in the Table 3, there was a highly significant difference in the frequencies of antinuclear antibody among the two groups $(80.0 \%$ versus $17.6 \%)$. The patterns of antinuclear antibody in PM-DM patients with herpes zoster were various, speckled and/or homogenous, but its tendency as similar in those patients without zoster.

Two of the five PM-DM patients with zoster infection overlapped other collagen disorders. One was overlap RA ${ }^{11)}$ and the other with SLE.

The two groups showed no significant difference in the frequencies of lung fibrosis, cardiac damage,

Table 3 Clinical Features in 22 patients with PM-DM

\begin{tabular}{lcc}
\hline & $\begin{array}{c}\text { Heros Zoster } \\
(\mathrm{n}=5)\end{array}$ & $\begin{array}{c}\text { Herpes Zoster } \\
(\mathrm{n}=17)\end{array}$ \\
\hline Age at oneset of PM-DM & & \\
$\quad$ Range(years) & $21-69$ & $25-60$ \\
$\quad$ Mean(years) & 46.2 & 46.2 \\
Females(male : female) & $80 \%(1: 4)$ & $70.6 \%(5: 12)$ \\
Lung fibrosis & $60 \%(3 / 5)$ & $35.3 \%(6 / 17)$ \\
Cardiac damage & $60 \%(3 / 5)$ & $29.4 \%(5 / 17 \%)$ \\
$\quad$ coronary insufficiency) & $0 \%(0 / 5)$ & $5.9 \%(1 / 17)$ \\
Raynaud's phenomenon & $80 \%(4 / 5)$ & $64.7 \%(11 / 17)$ \\
Anthritis & $80 \%(4 / 5)$ & $17.6 \%(3 / 17)$ \\
Positive RA test & $40 \%(2 / 5)$ & $29.4 \%(5 / 17)$ \\
Positive LE test & $20 \%(1 / 5)$ & $0 \%(0 / 17)$ \\
Positive microsome test & $20 \%(1 / 5)$ & $0 \%(0 / 17)$ \\
Positive thyroid test & $20 \%(1 / 5)$ & $5.9 \%(1 / 17)$ \\
Malignancy & $20 \%(1 / 5)$ & $5.9 \%(1 / 17)$ \\
Lung tuberculosis & $20 \%(1 / 5)$ & $11.8 \%(2 / 17)$ \\
Overlap syndrome* & $40 \%(2 / 5)$ & $0 \%(0 / 17)$ \\
\hline
\end{tabular}

*Statiatically significant difference, $\mathrm{p}<0.01$

1) Herpes zoster infected patients with PM-DM

2) Herpes zoster no infected patients with PM-DM 
Table 4 Administration of Prednisolone

\begin{tabular}{|c|c|c|c|c|}
\hline & $\begin{array}{l}\text { Average of } \\
\text { initial dose }\end{array}$ & $\begin{array}{l}\text { Duration of } \\
\text { steroid usage }\end{array}$ & $\begin{array}{l}\text { Average of } \\
\text { maintenance } \\
\text { dose }\end{array}$ & $\begin{array}{l}\text { Average of dose } \\
\text { at the time of } \\
\text { zoster infection }\end{array}$ \\
\hline $\begin{array}{c}\text { PM-DM with Herpes zoster } \\
\text { (5 patients) }\end{array}$ & $29.0 \mathrm{mg} /$ day & $\begin{array}{l}31 \text { months } \\
(1-59)\end{array}$ & $\begin{array}{l}13.1 \mathrm{mg} / \mathrm{day} \\
(4.2-20.0)\end{array}$ & $\begin{array}{l}6.5 \mathrm{mg} / \mathrm{day} \\
(0-12.5)\end{array}$ \\
\hline $\begin{array}{l}\text { PM-DM without Herpes zoster } \\
\text { (17 patients) }\end{array}$ & $33.4 \mathrm{mg} / \mathrm{day}$ & $\begin{array}{l}57 \text { months } \\
(11-119)\end{array}$ & $\begin{array}{l}13.9 \mathrm{mg} / \mathrm{day} \\
(0-25.0)\end{array}$ & - \\
\hline $\begin{array}{l}\text { SLE with Herpes zoster } \\
\text { (9 patients) }\end{array}$ & $19.6 \mathrm{mg} /$ day & $\begin{array}{l}60 \text { months } \\
(9-143)\end{array}$ & $\begin{array}{l}15.4 \mathrm{mg} / \mathrm{day} \\
(0-30)\end{array}$ & $\begin{array}{l}7.8 \mathrm{mg} / \mathrm{day} \\
(0-10)\end{array}$ \\
\hline $\begin{array}{r}\text { SLE without Herpes zoster } \\
\text { (13 patients) }\end{array}$ & $22.1 \mathrm{mg} /$ day & $\begin{array}{l}56 \text { months } \\
(6-127)\end{array}$ & $\begin{array}{l}14.6 \mathrm{mg} / \mathrm{day} \\
(0-20)\end{array}$ & - \\
\hline
\end{tabular}

Raynaud's phenomenon, arthritis, RA test, malignancy and lung tuberculosis.

Relationship between Herpes Zoster Infection and Treatment of PM-DM (Table 4)

All patients with PM-DM received steroid therapy alone and none was treated with immunosuppressive agents.

The average initial daily dose of prednisolone in PM-DM patients with or without herpes zoster infection was $29.0 \mathrm{mg}$ and $34.4 \mathrm{mg}$ respectively. No statistical difference was fond among the two groups.

The average maintenance dose of prednisolone in PM-DM patients with herpes zoster infection was $13.1 \mathrm{mg}$ daily (range 4.2-20). Though the interval to the development of herpes zoster from the onset of PM-DM ranged from 11 to 93 months (mean 38.6), the duration of steroid therapy prior to zoster development ranged from 1 to 59 months (mean 31). These patients were taking an average dose of $6.5 \mathrm{mg}$ of prednisolone daily (range $0-12.5$ ).

When steroid therapy was compared between the groups with and without herpes zoster infection there was no significant differences in either the initial dose, maintenance dose or duration of prednisolone therapy. In addition, one patient developed zoster 68 months after steroid therapy was terminated. Though the average of dose at the time of zoster infection in PM-DM patient $(6.5 \mathrm{mg} /$ day $)$ was similar that in SLE patient $(7.8 \mathrm{mg} /$ day), the duration of steroid therepy prior to zoster development in PM-DM patient was shorter (31 months) than that (60 months) in SLE patients.

\section{Discussion}

No detalied studies of PM-DM patients with zoster infections, to our knowledge, have been reported. Increased frequency of herpes zoster in patients with lymphoma (particularly Hodgkin's lymphoma), leukemia and malignancy has been reported in several studies ${ }^{511}{ }^{15)}$. Incidences of zoster in Hodgkin's disease were most frequent and ranged from 8 to $73 \%^{13114)}$. Among hospitalized patients the frequency of herpes zoster was found to be $0.26 \%$ of 55,179 patients during a 4 -year period ${ }^{13}$. Though the frequency per year of herpes zoster infection in the general population was reported to be 48 per thousand $(0.04 \%$ per month $)^{11)}$, in this study of 22 patients with PM-DM, 22.8\% developed zoster, the incidence is less than that in those with SLE.

The association of zoster with SLE has been observed by several authors ${ }^{16 \sim 18)}$ and showed as follows: 1 ) the course of herpes zoster was uneventful, 2) multiple episodes were often observed, 3) the majority of SLE patients developed zoster within 3-4 years after the onset of SLE, 4) zoster occurred when lupus activity was relatively minimal.

Our study showed that the clinical courses of zoster infections were uneventful; no severe complications nor deaths occurred and only one patient developed posttherapeutic neuralgia, and that zoster tended to occur in the inactive stage of PM-DM. In addition, no specific therapy for this infection was necessary. On the other hand, it was different from SLE that there were no multiple infections in patients 
with PM-DM and that this infection occurred in varius durations after the onset of PM-DM.

The possible predisposig factors associated with an increased incidence of herpes zoster in PM-DM patients showed the following speculations and observations.

Recent evidence supports a variety of immunopathogenesis in PM-DM. For example, Johnson and co-workers showed that lymphocytes from patients with PM produced factor which destroys muscle cells and that this activity is blocked by corticosteroids ${ }^{11}$. In addition, detection of immune complex, abnormality of macrophage migration inhibitory factor have been reported in PM-DM patients ${ }^{19 \sim 20}$. It has been speculated that defective immunity is found spontaneously and induced by the immunosuppressive agents such as corticosteroids, in PM-DM patients. These systemic effects may depress host resistance to the virus and permit reactivation of latent virus.

When compared to the group without zoster infection, patients with herpes zoster had a significantly higher incidence of antinuclear antibody. A etiology of this correlation is not clear. In recent years, assay for autoantibodies to calf thymus nuclear extract has been reported by several investigators ${ }^{12222}$. It is considered to be necessary to examine a more detailed study for autoantibodies to nuclear antigens in our patients and more incidences of zoster infection in other diseases showing a positive antinuclear antibody.

In our series, there was no correlation between steroid therapy and the occurrence of zoster infection. But the overall PM-DM patients with zoster infection were treated with corticosteroids, and there is the possibility of unknown factors which predisposed development of zoster in our patients.

Thus, the development of herpes zoster in our PM-DM patients might be related to several predisposing factors.

Acknowledgement We thank Miss Yasuko Fujimura for preparation of this manuscript.

\section{References}

1) Johnson, R.L., Fink, C.W. \& Ziff, M.: Lymphotoxin formation bylmphocytes and mucle in polymyositis. J. Clin. Invest., 51 2435-2448, 1972.

2) Dawkins, R.L.: Review. Experimental autoallergic myositis, polymyositis and myasthenia gravis. Autoimmune muscle disease associated with immunodeficiency and neoplasia. Clin. Exp. Immunol., 21: 185-201, 1975.

3) Wollheim, F.A.: Acute and long-term complications of corticosteroid pulse therapy, Scand. J. Rheumatol. (Suppl), 54: 27-32, 1984.

4) Miller, L.H. \& Brunell, P.A.: Zoster, reinfection or activation of latent virus? Am. J. Med., 49: 480—483, 1970.

5) Mazur, M.H. \& Dolin, R.: Herpes zoster at the NIH: A 20 year experience. Am. J. Med., 65: 728-744, 1978.

6) Bohan, A. \& Peter, J.B.: Polymyositis and dermatomyositis. N. Engl. J. Med., 292: 344-347, 1975.

7) Tan, E., Cohen, A.S., Fries, J.F., Masi, A.T., McShane, D.J., Rothfield, N.F., Schaller, J.G., Talal, N. \& Winchester, R.J.: The 1982 revised criteria for the classification of systemic lupus erythematosus Arthritis Rheum., 25: 12711277, 1982.

8) Beck, J.S.: Variations in the morphological patterns of "autoimmune" nuclear fluorescence. Lancet, 1: 1203-1205, 1961.

9) Hughes, G.R.V.: Significance of anti-DNA antibodies in systemic lupus erythematosus. Lancet, 2: 861-863, 1971.

10) Gold, E. \& Godek, G.: Complement fixation studies with a varicellazoster antigen. J. Immunol., 96: 692-695, 1965.

11) Nagaoka, S., Sakamoto, H., Narita, M., et al.: A case of reumatoid arthritis with polymyositis (Japanese). Rhumachi., 21: 393-399, 1981.

12) McGregor, R.M.: Herpes zoster, chicken-pox and cancer in general ractice. Br. Med. J., 1: 84-87, 1957.

13) Wright, E.T. \& Winer, L.H.: Herpes zoster and malignancy. Arch. Dermatol., 84: 242-244, 1971.

14) Feldman, S., Hughes, W.T. \& Kim, H.Y.: Herpes zoster in children with cancer. Am. J. Dis. Child., 126: 178-184, 1973.

15) Goffinet, D.R., Glaststein, E.J. \& Merigan, T.C.: Herpes zoster-varicella infections and lymphoma. Ann. Intern. Med., 76: 235-240, 1972.

16) Hamaguci, T., Kotani, Y. \& Imanaka, S.: Lupus erythematosus and herpes zoster. M.I.E. Med. J., 19: 189-192, 1970.

17) Ginzler, E., Diamond, H., Kaplan, D., et al.: Computer analysis of factors influencing frequency of infection in systemic lupus erythematosus. Arthritis Rheum., 21: 37-44, 1978. 
18) Moutsopoulos, H.M., Gallagher, J.D., Decker, J.L., et al.: Herpes zoster in patients with systemic lupus erythermatosus. Arthritis Rheum., 21: 798-802, 1978.

19) Behan, W.M.H., Barkas, T., Behan, P.O.: Detection of immune complexes in polymyositis. Acta Neurol. Scand., 65: 320-324, 1982.

20) Smith, P.D. \& Partridge, T.A.: Macrophage migration inhibition studies of lymphocytes taken from guinea-pigs suffering from experimental polymyositis. Clin. Exp. Immunol., 25: 133-138, 1976.

21) Wolfe, J.F., Adelstein, E. \& Sharp, G.C.: Antinuclear antibody with distinct specificity for polymyositis. J. Clin. Invest., 59: 176-178, 1977.

22) Nishikai, M. \& Reichlin, M.: Heterogeneity of precipitating antibodies in polymyositis and dermatomyositis. Characterization of te Jo-1 antibody system. Arthritis Rheum., 23: 881-888, 1980.

\section{多発性筋炎患者和よび皮膚筋炎患者に括ける帯状包疹}

\begin{tabular}{lrlrl}
\multicolumn{4}{c}{ 横浜市立大学第 1 内科 } \\
長岡 & 章平 & 谷 & 賢治 & 石ヶ坪良明 \\
千場 & 純 & 加藤 & 清 & 松永敬一郎 \\
成田 & 雅弘 & 五十嵐俊久 & 大久保隆男
\end{tabular}

(平成 63 年 6 月 22 日受付)

(平成 2 年 5 月 1 日受理)

多発性筋炎 (皮膚筋炎) 患者に打ける帯状包疹 症の臨床的特徴を解析する目的で, 22名の本症患 者, 20 名のホジキンリンパ腫症患者, 22 名の全身 性エリテマトーデス患者を対象として, 病歴を検 討し，その臨床像を分析した。

健常人に打ける帯状包疹の発症率は $0.003 \% /$ 年 であるが，多発筋炎（皮虐筋炎）患者のそれは $0.13 \% /$ 年, ホジキンリンパ腫症患者のそれは $0.18 \% /$ 年, 全身性エリテマトーデス患者のそれは $0.24 \% /$ 年であった.
多発筋炎（皮膚筋炎）患者に打ける帯状包疹症 の臨床的特徵は以下の通りである。（1）治療後の 神経痛が 1 例あったが, 重篤な合併症はなく, 死 亡例もなかった（2）本症に特殊な治療法の必要 はなかった。（3）多発筋炎（皮膚筋炎）の非活動 期に本症が発症する傾向があった。（4）本症が発 症した患者では，抗核抗体が高値を示した。

本症の発症と, ステロイド剤の初期投与量, 維 持量, 投与期間との間の相関は認められなかった。 